\title{
EFFECT OF SHADING ON Dimorphandra gardneriana TUL. SEEDLING PRODUCTION
}

\author{
EFEITO DO SOMBREAMENTO NA PRODUÇÃO DE MUDAS DE Dimorphandra \\ gardneriana $T U L$.
}

\author{
Sueli da Silva SANTOS-MOURA ${ }^{1}$; Edna Ursulino ALVES ${ }^{2}$; Marina Matias URSULINO³; \\ Riselane de Lucena Alcântara BRUNO²; Antônio Pereira dos ANJOS NETO ${ }^{4}$ \\ 1. Professor at the Federal Institute of Alagoas (IFAL), Brazil. sssantosagro@ hotmail.com; 2. Professors of the Federal University of \\ Paraíba, Center for Agrarian Sciences (CCA-UFPB), Brazil; 3. PhD in agronomy, Federal University of Paraíba (CCA-UFPB), Brazil; \\ 4. Master of the Graduate Program in Plant Science, "Luiz de Queiroz" School of Agriculture, Brazil.
}

\begin{abstract}
The study of plant behavior in environments with different luminous intensities offers information about their ability to modify their growth and performance in response to light. The objective of this study was to evaluate the influence of shading on the development of Dimorphandra gardneriana Tul. Different levels of shading were used, with $0 \%$ shading (full sun) - $\left(\mathrm{T}_{1}\right), 30 \%-\left(\mathrm{T}_{2}\right), 50 \%-\left(\mathrm{T}_{3}\right)$ and $70 \%$ shading - $\left(\mathrm{T}_{4}\right)$. The different levels of shading were obtained by means of black polyolefin screens, sombre type, each treatment consisting of four replicates of 15 plants. The evaluated characteristics were: number of leaves, plant height, neck diameter, survival percentage, shoot length and primary root, green and dry mass of shoots and roots, total dry mass, Dickson quality index and (AP/MSPA), shoot height and diameter (A/DC), aerial part and root dry mass (MSPA/MSR), shoot height and dry mass (CPA/CR), as well as the percentage of roots $(\% \mathrm{R})$. The shading influenced negatively the quality of $D$. gardneriana seedlings, being those grown in full sun the ones that presented the best quality. Based on the morphological parameters studied, it can be affirmed that the D. gardneriana Tul., seedlings, produced in an open environment with high luminosity showed superior qualities in relation to the shaded seedlings.
\end{abstract}

KEYWORDS: Fava d'anta. Forest. light.

\section{INTRODUCTION}

The tree species, Dimorphandra gardneriana Tul., known as faveira or fava d'anta is a legume from the Fabaceae that can reach up to 10 meters high. It has a panicle inflorescence type, with short spikes and yellow flowers. Flowering occurs in the rainy season, more precisely in December, and fruiting begins in January until August and September (RIBEIRO-SILVA et al., 2012). The fruit is an indehiscent flat legume, ranging from dark brown to almost black in color; it is opaque, with a rough, irregular surface with a rounded apex and base, and is used for the extraction of rutin, an important flavonoid used in the pharmaceutical industry (RIBEIRO-SILVA et al., 2007; LANDIM; COSTA, 2012).

Flavonoids are phenolic compounds that have roused considerable interest recently because of their potential beneficial effects on human health, such as a circulatory stimulant, and are, therefore, used in mesotherapy or intradermotherapy against cellulite (LANDIM; COSTA, 2012). Rutins were described by Chen et al. (2013) a natural therapeutic drug with the potential for treating neuroblastomas, which are malignant neuroblast tumors that occur in the adrenal gland and are frequent in children during the first year of life. There are also reports that flavonoids can prevent prostate cancer (GEYBELS et al., 2013).

Dimorphandra gardneriana is typical of the cerrado and caatinga ecosystems of Brazil, and occurs naturally in the states of Maranhão, Piauí, Ceará, Pernambuco, Bahia, Pará, Goiás, Mato Grosso, and Minas Gerais (MONTANO et al., 2007). Regarding Ceará, the National Araripe Forest has great biodiversity, including $D$. gardneriana Tul., which was explored for the extractive form at this location (RIBEIRO-SILVA et al., 2012).

The harvest of fruits for rutin extraction reduced seed dispersion, which is a risk to the maintenance of species. Therefore, it is important to emphasize that the management and conservation of the species depends on a better understanding of the ecological implications of its fruit extraction (RIBEIRO-SILVA, 2007; RIBEIRO-SILVA et al., 2012).

Seedling production in nurseries is one of the most important phases of the forest stand implementation process (COSTA et al., 2008); however, the success of a planting depends on the quality of seedlings produced, especially the morphological and physiological quality, and these characteristics are influenced by the seed origin, methods used in seedling production, management, equipment, nursery structures, as well as the 
environmental conditions at the site where the seedlings are produced (CARON et al., 2010).

Among the environmental factors that directly affects forest seedling production is the light requirement of the species, including light intensity, quality, and duration, since the availability of radiation is an important factor in energy flow in biological systems, and depending on the ability to capture and use light, the responses of plants are different and crucial for their survival, growth, and adaptation to different environments (SARAIVA et al., 2014; AZEVEDO et al., 2015). With this, Dutra et al. (2015) emphasized that changes of growth efficiency can be associated with the ability of plants to adapt to the environmental light conditions.

Shading is a technique used to protect plants from the harmful rays of the sun, especially during periods of high energy availability, as well as contributing to ameliorating the plant temperature, which may positively affect the growth rate and quality of seedlings, as the ecological class of the species (CARON et al., 2010).

The light intensity requirement of different species in the initial phase varies, for example, Schizolobium parahyba (Vell.) S. F. Blake can be produced in shadings of $30 \%, 50 \%$, and $70 \%$, obtaining quality seedlings with stem height and diameters compatible for transplanting, but its exposure to shade should not exceed 45 days, since from that period the plants begin the process of blanching (CARON et al., 2010). However, Azevedo et al. (2015) found that Azadirachta indica A. Juss seedlings produced in full sun had a better quality standard based on the morphological characteristics, such as stem diameter, height/diameter, fresh and dry mass of roots, number of leaves, and the Dickson index quality.

The objective of the present study was to evaluate the effect of shading on D. gardneriana Tul. seedling development.

\section{MATERIAL AND METHODS}

The work was carried out in the forest nursery of the Laboratory of Plant Ecology (LEV), Department of Plant and Environmental Sciences, Center of Agricultural Sciences, Federal University of Paraíba in Areia - PB. The seeds were obtained from fruits harvested in mother plants located in forest remnants near the cities of Jardim (Latitude: $07^{\circ} 34^{\prime}$ 57" S and Longitude: $39^{\circ} 17^{\prime} 53^{\prime \prime} \mathrm{W}$ ) and Crato (Latitude: $07^{\circ} 14^{\prime} 03^{\prime \prime} \mathrm{S}$ and Longitude: $39^{\circ}$ 24' 34" W), Ceará State.

After harvesting, the fruit was manually processed at collection site, and subsequently the seeds were placed in plastic bags and transported to the Seed Analysis Laboratory (LAS) where they were placed in plastic containers and stored in a cold chamber $15^{\circ} \mathrm{C}$ for two years, when they were used for the experiment.

To verify the plant requirements for light intensity, different levels of shading were used, including $0 \%$ (full sunlight; $\left.\mathrm{T}_{1}\right), 30 \%\left(\mathrm{~T}_{2}\right), 50 \%$ $\left(\mathrm{T}_{3}\right)$, and $70 \%\left(\mathrm{~T}_{4}\right)$ shading. These levels were evaluated at 30 days after transplanting at 21 day intervals. To obtain the different levels of shading, the seedlings were placed under wooden frames (approximately $1.5 \times 1.0 \times 1.0 \mathrm{~m}$ ) that were covered on the top and sides with black polyolefin shadingtype screens, and each treatment consisted of four replicates of 15 plants. The design used in the experiment was completely randomized with four replications of 15 plants per treatment.

Before the experiment was carried out, seeds were sown in plastic trays $(49 \times 33 \times 7 \mathrm{~cm})$ containing vermiculite, where the seeds after overcoming dormancy, by lopping opposite the hilum (URSULINO, 2013) were sown at a depth of $2 \mathrm{~cm}$ and kept in the shade for 15 days. Subsequently, seedlings were transferred to a greenhouse for five days to acclimate, and thereafter each plant was transplanted to a polyethylene bag $(15 \times 28 \mathrm{~cm})$. The substratum used was topsoil and the plants were kept under different levels of shading for 93 days, and during this period the humidity of the substrate was maintained by daily watering.

Characteristics evaluated were:

Number of leaves: recorded from 30 days after transplanting at 21 day intervals, counting all the leaves present on each plant, up to 93 days after transplanting, when the experiment was completed.

Plant height: determined using a ruler graduated in centimeters, measuring from the base of the stem to the insertion of the last leaf, from 30 to 93 days after transplanting at 21 day intervals, and the results were expressed in $\mathrm{cm} /$ plant.

Stem diameter: measured at the plant's lap, with the aid of a digital caliper rule, from 30 to 93 days after transplanting, at 21 day intervals, and the results were expressed in millimeters.

The relationship between plant height and stem diameter (AP/DC): determined by dividing the plant height by the diameter of the lap, from 30 to 93 days after transplanting at 21 day intervals.

Percentage survival: analyzed at the end of the experiment by recording the number of plants in each treatment.

Shoot and primary root length: at the end of the experiment, plants of each treatment were 
measured (root and shoot) using a ruler graduated in centimeters and the results were expressed in plant $\mathrm{cm}^{-1}$.

Shoot and root green mass: after the previous measurement plants of each treatment and repetition were separated into roots and shoots and weighed using an analytical balance accurate to $0.0001 \mathrm{~g}$ and the results were expressed in $\mathrm{g}$ per plant $^{-1}$.

Shoot and root dry mass: after previous evaluations, the same plants separated into roots and shoots were placed in paper bags and placed in a forced ventilation oven at $65{ }^{\circ} \mathrm{C}$ for 48 hours. After this period, the samples were weighed using an analytical balance accurate to $0.0001 \mathrm{~g}$ and the results expressed in $\mathrm{g}$ per plant $^{-1}$.

Total dry mass: after the determination of the dry mass of roots and shoots, the total dry mass was determined by the sum of the dry weight of roots and shoots, and the results were expressed in $g$ per plant ${ }^{-1}$.

Dickson quality index (DQI): determined according to the weight of the total dry matter (MST), plant height (A), stem diameter (DC), dry weight of shoot (MSPA) and root (MSR) by the formula of Dickson et al. (1960).

The ratio between shoot and root dry mass (MSPA/MSR): at the end of the experiment, after obtaining the above variables, the division between the dry mass of shoots and roots was performed.

Ratio between plant height and shoot dry mass (AP/MSPA): obtained by dividing plant height and dry weight of shoots, which is considered the dry mass of stem and leaves.

Ratio of length of shoots and primary roots (CPA/CR): obtained by dividing the length of the shoots and primary roots.

Percentage of roots $(\mathrm{R} \%)$ : determined by dividing the dry root weight by the total dry mass and the result multiplied by 100 , using the formula: $\%$ ROOT $=$ MSR/MST $\times 100$.

Growth was assessed by height, diameter, and leaf number, and treatments were arranged in a split plot where the plots were composed of shading levels and the subplots were composed of the assessments over time. Multiple regression analyses were used to analyze the data over time; the data of the final evaluation were subjected to polynomial regression analysis by testing linear and quadratic models. The Pearson correlation was applied to verify the relationship between two or more variables.

\section{RESULTS AND DISCUSSION}

The number of leaves and height of $D$. gardneriana seedlings were influenced by levels of shading and evaluation periods (Figure 1A-B), observing that at both 30 and 93 days of evaluation, the number of leaves was lowest in seedlings grown in full shade $(70 \%)$; however, this variable increased with time (Figure 1A). For plant height, it was found that the highest values were obtained from seedlings raised in $70 \%$ shading, and the values increased with time (Figure 1B).
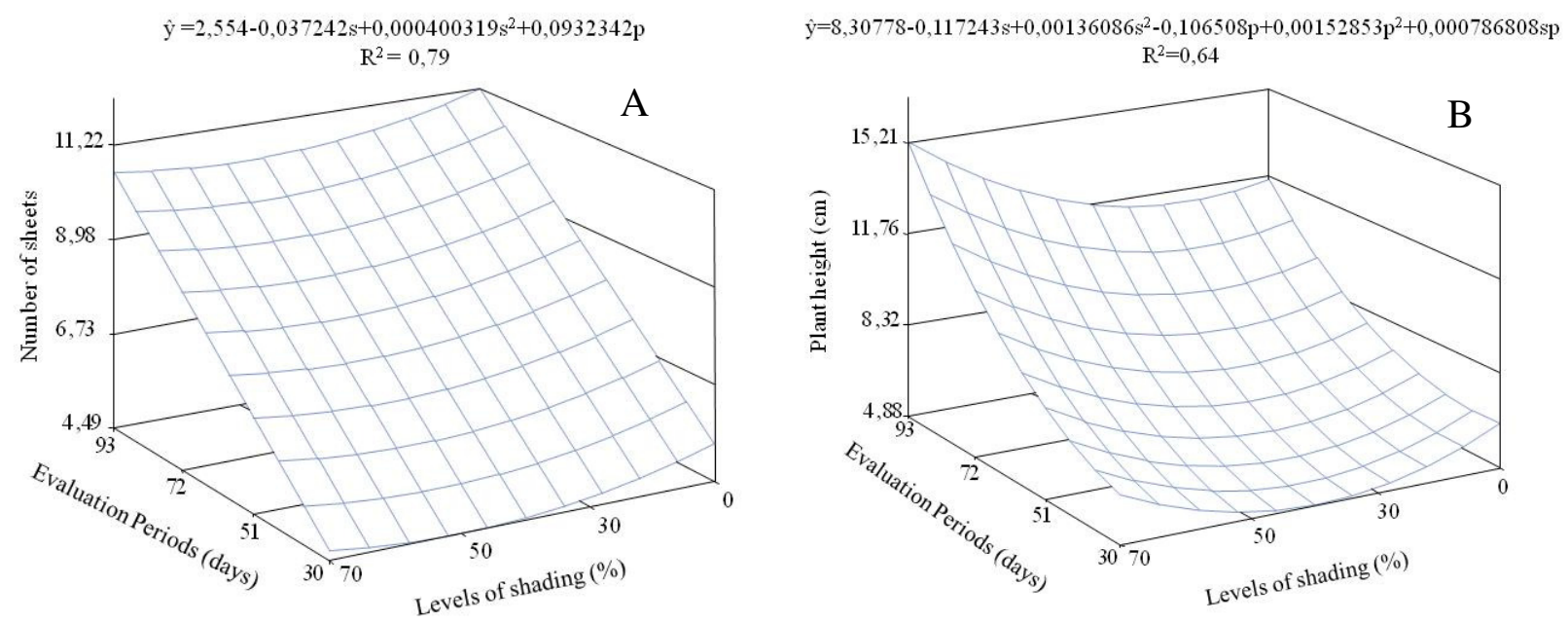

Figure 1. Number of leaves (A) and height (B) of Dimorphandra gardneriana seedlings produced at different levels of shading. 
The number of leaves of the seedlings grown under full sunlight was higher than that for shaded plants, but in seedlings exposed to full sunlight the leaves and plant height were noticeably reduced than those grown in shade. This could be a mechanism of species adaptation to low light environments, and increased leaf surface area, to increase the uptake of light and the photosynthetic rate.

Leaf expansion in low light conditions is a frequently reported behavior and indicates how plants more effectively utilize low light (LIMA et al., 2008) because depending on the skill of capture and use of light, the responses of plants are distinct and crucial for their survival, growth, and adaptation to different environments (SARAIVA et al., 2014).

Data regarding to the ratio height/diameter and stem diameter of $D$. gardneriana seedlings did not fit the multiple polynomial regression models, evidencing little variation in height/diameter in the treatments and evaluation period. However, these values tended to increase with increasing shading, where as the diameter demonstrated increasing values, but at day 93, similar values were obtained for all levels of shading, but there was a higher increase in seedling diameters exposed to $30 \%$ shade and full sun (Table 1).

Table 1. Ratio height/diameter and stem diameter of Dimorphandra gardneriana seedlings produced at different levels of shading.

\begin{tabular}{ccccccccc}
\hline Níveis de & \multicolumn{3}{c}{ Relação altura/diâmetro } & \multicolumn{3}{c}{ Diâmetro do caule (mm) } \\
\cline { 2 - 9 } sombreamento (\%) & \multicolumn{3}{c}{ Períodos de avaliação } & \multicolumn{4}{c}{ Períodos de avaliação } \\
\cline { 2 - 9 } & 30 & 51 & 72 & 93 & 30 & 51 & 72 & 93 \\
\hline 0 & 4,17 & 4,22 & 4,28 & 4,68 & 1,5 & 1,7 & 2,0 & 2,5 \\
30 & 4,05 & 4,28 & 4,71 & 5,18 & 1,3 & 1,5 & 1,9 & 2,5 \\
50 & 3,65 & 4,25 & 4,41 & 4,88 & 1,5 & 1,5 & 1,8 & 2,2 \\
70 & 5,43 & 5,46 & 5,96 & 7,89 & 1,2 & 1,5 & 1,8 & 2,1 \\
\hline
\end{tabular}

The highest ratio of height/diameter was obtained from seedlings exposed to $70 \%$ shading and as light availability increased this was reduced, which may have been owing to a higher increase in the diameter of the exposed plants in higher light concentrations. For seedlings of Toona ciliata M. Roem var. australis produced without shading, the lowest height/diameter was not synonymous of quality, because the seedlings grown in full sun were necrotic, which had negative influence on the increase in height (MARCO et al., 2014).

Greater increases in height were also observed by Freitas et al. (2012) in seedlings of Sclerolobium paniculatum Vogel when subjected to $50 \%$ shading than those seedlings grown in full sun. However, the maximum height of Copaifera langsdorffii Desf. seedlings was achieved with $63 \%$ shading (DUTRA et al., 2015).

Seedlings of Ochroma pyramidal (Cav. Ex Lam.) were influenced by different shadings, with the highest growth (height and diameter) occurring under $30 \%$ shading achieved using a reflective screen of $50 \%$ (Santos et al., 2014). In the study by Azevedo et al. (2015), using different shading levels $(0 \%, 30 \%, 50 \%$, and $70 \%)$ in the production of seedlings of Azadirachta indica A. Juss, the highest height and diameter values, and lowest height/diameter ratios were obtained from seedlings produced full sun.
However, Dipteryx alata Vog. seedlings produced in environments with $0 \%, 30 \%, 50 \%$, and $70 \%$ shading showed better performance in stem diameter than those produced in full sun and 30\% shading, but the height and leaf number were higher for seedlings at $30 \%$ shaded (QUEIROZ; FIRMINO, 2014). By studying the behavior of Schizolobium amazonicum Huber ex Ducke seedlings in full sun environment, $75 \%$ shade, and greenhouse, Frigotto et al. (2015) observed that plant height, stem diameter, and number of leaves of seedlings grown in full sun were significantly lower than that of the other treatments.

Therefore, it is evident that the plant performance in relation to light is varied, and different species behave differently when subjected to different environments, which makes it important to determine the behavior of various species when exposed to different light intensities.

For the length of the primary root and DQI of $D$. gardneriana seedlings, the linear regression mode indicated significant reductions with increased shading levels, whereas the shoot length and percentage survival did not fit the polynomial regression models, with mean values of $13.59 \mathrm{~cm}$ and $91 \%$, respectively (Figure 2A-D).

The length of the primary root was negatively affected by shading levels, with the highest values observed in seedlings grown in full 
sun, possibly owing to the need for greater water absorption owing to the high evapotranspiration rate, which is in accordance with the studies of Lei and Lechowicz (1998) and Poorter (1999), who reported this as functionally accurate: owing to the greater evapotranspiration demand, increased investment in dense root system growth assumes greater importance in plants under conditions of high irradiance than those in shaded environments.


Figure 2. Length of the primary root (A), the shoot (B), Dickson quality index (C) and survival percentage (D) of Dimorphandra gardneriana seedlings produced at different levels of shading.

Therefore, Gomes and Paiva (2013) argued that good root development can ensure better performance in the field, given that they are closely related to the physiological activities of plants in complex soil-water-plant environments. For Ochroma pyramidal (Cav. Ex Lam.) Urb. seedlings, the difference in shading environments (shading $30 \%$ and $50 \%$, open field, term reflector $30 \%$ and $50 \%$ ) did not affect the length of the primary root (SANTOS et al., 2014), whereas for length of the primary root of Dipteryx alata Vog seedlings it was highest in $50 \%$ and $70 \%$ shade than that of other shading levels (0-30\%) (QUEIROZ and FIRMINO, 2014).

The shoot length data did not fit the regression models, but there was a growing trend at the highest level of shading (Figure 2). According to Marco et al. (2014) shaded plants tend to have greater height owing to light deficiency and therefore blanching occurs. The percentage of $D$. gardneriana seedling survival was not influenced by levels of shading used in nursery, with high percentages in all treatments.

For seedlings of Copaifera langsdorffii Desf., the 50\% shading level showed a higher survival percentage (DUTRA et al., 2015), whereas Schizolobium amazonicum Huber ex Ducke seedlings produced in open fields had only a $42 \%$ survival, which was attributed to the presence of frost in the region (FRIGOTTO et al., 2015).

Dimorphandra gardneriana seedlings produced in full sun showed higher a DQI, and may be considered better quality than the shaded seedlings, since other important variables, such as height, diameter and dry mass of roots and shoots was taken into account. According to Fonseca et al. (2002), DQI is a good indicator of seedling quality because changes in the strength and balance of the distribution of biomass are assessed, and several important parameters are used to assess the quality.

The DQI of Sclelorobium paniculatum seedlings grown under different levels of shading (natural shade, $50 \%$ shade, and full sun) was significantly different from that of seedlings grown in full sun, which exhibited better quality than those grown in shade (FREITAS et al., 2012). For Toona ciliata var. australis, seedlings the best DQI was achieved when a simple shading layer was used (MARCO et al., 2014). 
The different levels of shading $(0 \%, 30 \%$, $50 \%$, and $70 \%$ ) influenced the quality of Azadirachta indica seedlings, with the highest DQI values obtained from seedlings grown in full sun (AZEVEDO et al., 2015). The DQI was also considered by Dutra et al. (2015) as an excellent variable to indicate the standard of seedling quality of Copaifera langsdorffii Desf., since the seedlings with the highest rates had maximum total dry mass and shoot values.
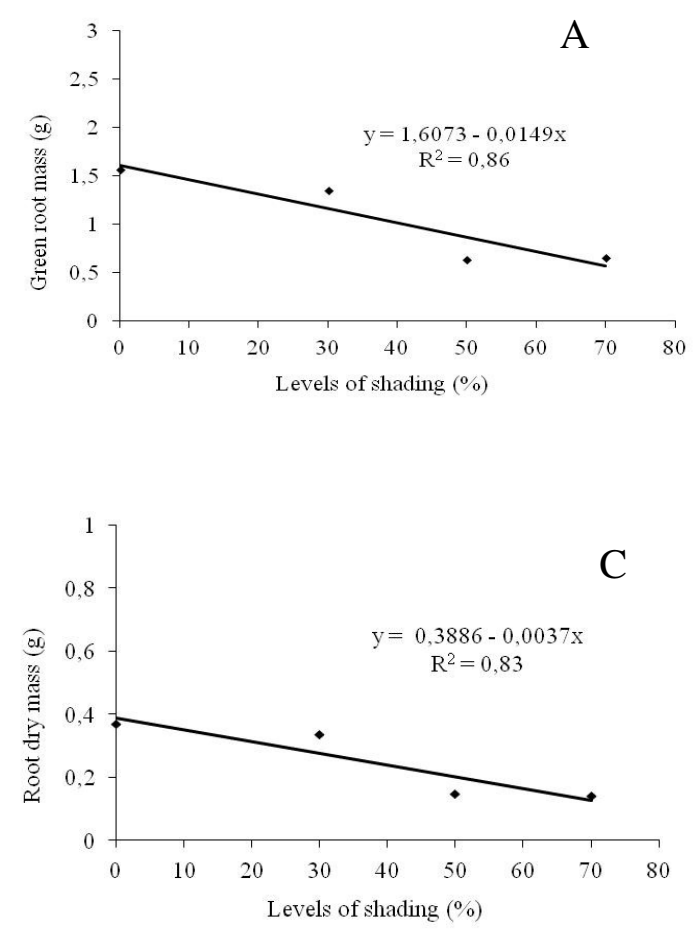

The data of green and dry mass of roots and shoots, as well as the total dry mass of $D$. gardneriana seedlings fit the linear regression model, with significant reductions in terms of shading levels (Figure 3A-E). This emphasized that seedlings grown in full sun had a higher content of green mass, dry and total mass, whereas the masses from seedlings produced in $70 \%$ shading were lower because the total dry mass decreased from 1.28 (zero shading) to $0.70 \mathrm{~g}$ (70\% shading).

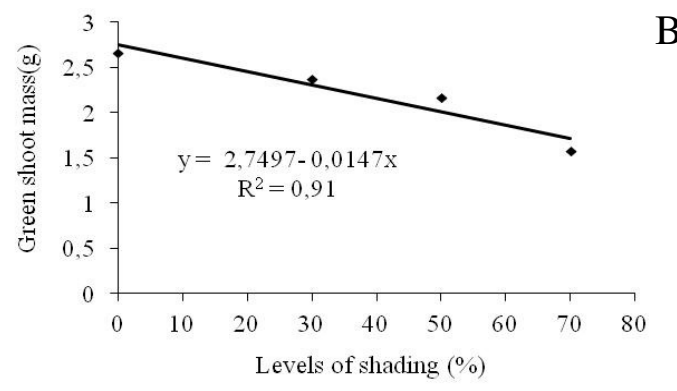

B
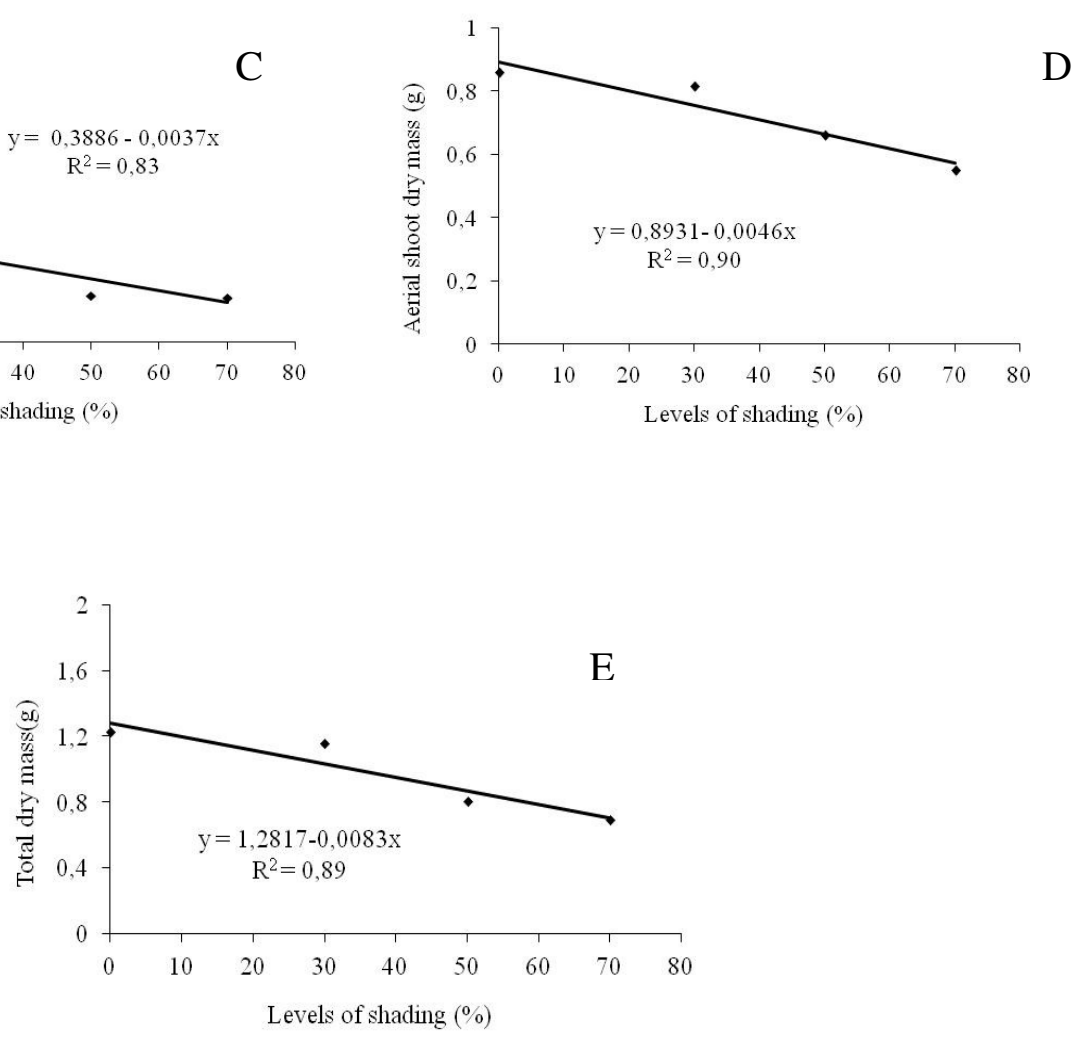

Figure 3. Green root mass (A), green shoot mass (B), dry roots mass (C), dry shoot mass (D) and total dry mass (E) of Dimorphandra gardneriana seedlings produced at different levels of shading.

In $70 \%$ shade, only $30 \%$ light was available for the plants, which may have contributed to the lower content of fresh and dry mass since the reduction in light availability causes a decrease in photosynthetic rate, and according to Floss (2004), a plant exposed to the sun can photosynthesize almost three times more than a shaded plant. Therefore, light availability is a key factor in the flow of energy in biological systems and is crucial for the 
physiological processes of plants (SARAIVA et al., 2014).

Among the morphological characteristics that determine seedling quality, the dry matter content has been considered one of the best because the survival and early growth are related to it (GOMES; PAIVA, 2013). In this study, it was found that seedlings grown in full sun were the most productive since the biomass was considerably higher than that of seedlings grown in shaded treatments.

Light has a considerable influence on several morphological, anatomical, and physiological plant characteristics, and the leaves of plants growing in full sun have more chloroplasts, a higher chlorophyll content, greater leaf thickness, which explains why plants growing in high light conditions are more efficient (FLOSS, 2004). In this context, Santos et al. (2013) stated that brightness controls the processes responsible for the accumulation of dry mass, contributing to seedling growth.

The dry weight of leaves, stems, and roots, as well as the total dry mass of Caesalpinia ferrea Mart. ex. Tul. seedlings were higher when produced in full sun than those produced in shades of $50 \%$ and $70 \%$ shade (LIMA et al., 2008). For Schizolobium parahyba (Vell.) seedlings, Caron et al. (2010) found that shading levels of $0 \%, 30 \%$, $50 \%$, and $70 \%$ did not affect the dry matter accumulation in different parts of the plant.

The quality of Ochroma pyramidal (Cav. Ex Lam.) seedlings was influenced by the tested shading $(30 \%$ and $50 \%)$, which had a positive effect on plant growth, and resulted in the highest fresh and dry mass content of shoots and root s( SANTOS et al., 2014). The dry weight of shoots and roots of Dipteryx alata Vog. seedlings was higher in $70 \%$ shading, with 3.37 and $2.47 \mathrm{~g}$, respectively, compared to that of other shading levels (0-30\%), and the authors attributed these results to the larger number of leaves and higher root length obtained with this shading (QUEIROZ and FIRMINO, 2014).

For the relationship between the dry weight of shoots and roots, plant height and dry weight of shoot, shoot length and primary root a linear model was fitted, which increased with increasing shading levels (Figure 4A-C). However, the percentage of roots decreased linearly with increasing shading levels (Figure 4D).

The lowest evaluated relations were observed in seedlings grown in full sun, indicating that these are of superior quality, since the relationship between the dry weight of shoots and roots is an important variable in determining the quality of seedlings, and established the value of 2.0 as the best relationship between these two factors, whereas the relationship between plant height and weight of shoot can predict the potential for survival in the field, so that the lower this is more resistant index is the changes and increased its survivability (GOMES; PAIVA, 2013).

In plant growth, there is an interdependence between the functioning of the root system and shoot, for example, in seedlings grown in full sun there was a lower ratio between the length of shoots and primary roots owing to the higher growth of the primary root; however, in shaded seedlings the development of more shoots was prioritized, and so a greater relationship between these two structures occurred.

This can be corroborated with the results of the percentage of roots where the lowest values occurred in the shaded plants (Figure 4D), and according to Fonseca et al. (2002), morphological characteristics and relationships used to evaluate seedling quality should not be used alone to reduce the risk of selecting seedlings with higher root percentages, although they are weak, or discarding smaller yet more powerful seedlings.

In a study by Freitas et al. (2012), Sclelorobium paniculatum Vog. seedlings grown in different conditions (natural shade, $50 \%$ shade, and full sun) had a lower shoot/root ratio under full sun, possibly because the plants grown in high light intensities had a higher allocation of assimilates to the roots. In Caesalpinia ferrea Mart. Ex Tul., seedlings produced in full sun, Santos et al. (2013) found a lower ratio of the dry mass of shoots and roots.

It was found that there was no significant Pearson correlation between the length of shoots and green mass of roots and dried mass of roots, the total dry mass, and primary root length, but these variables are correlated significantly positively among them; however, there was a significant negative correlation between shoot length and green mass shoots and dry mass of shoots, indicating that the increase implies a decrease in the other (Table 2).

The DQI is strongly correlated with all variables, except for the length of shoots, but the correlation of DQI with the ratios of dry mass of shoots and roots, height plant, and dry weight of shoot, shoot length and primary ratio was significant and negative. However, these same ratios were correlated significantly and negatively with the mass of roots and root length, but significantly and positively with the shoot length (Table 2). 

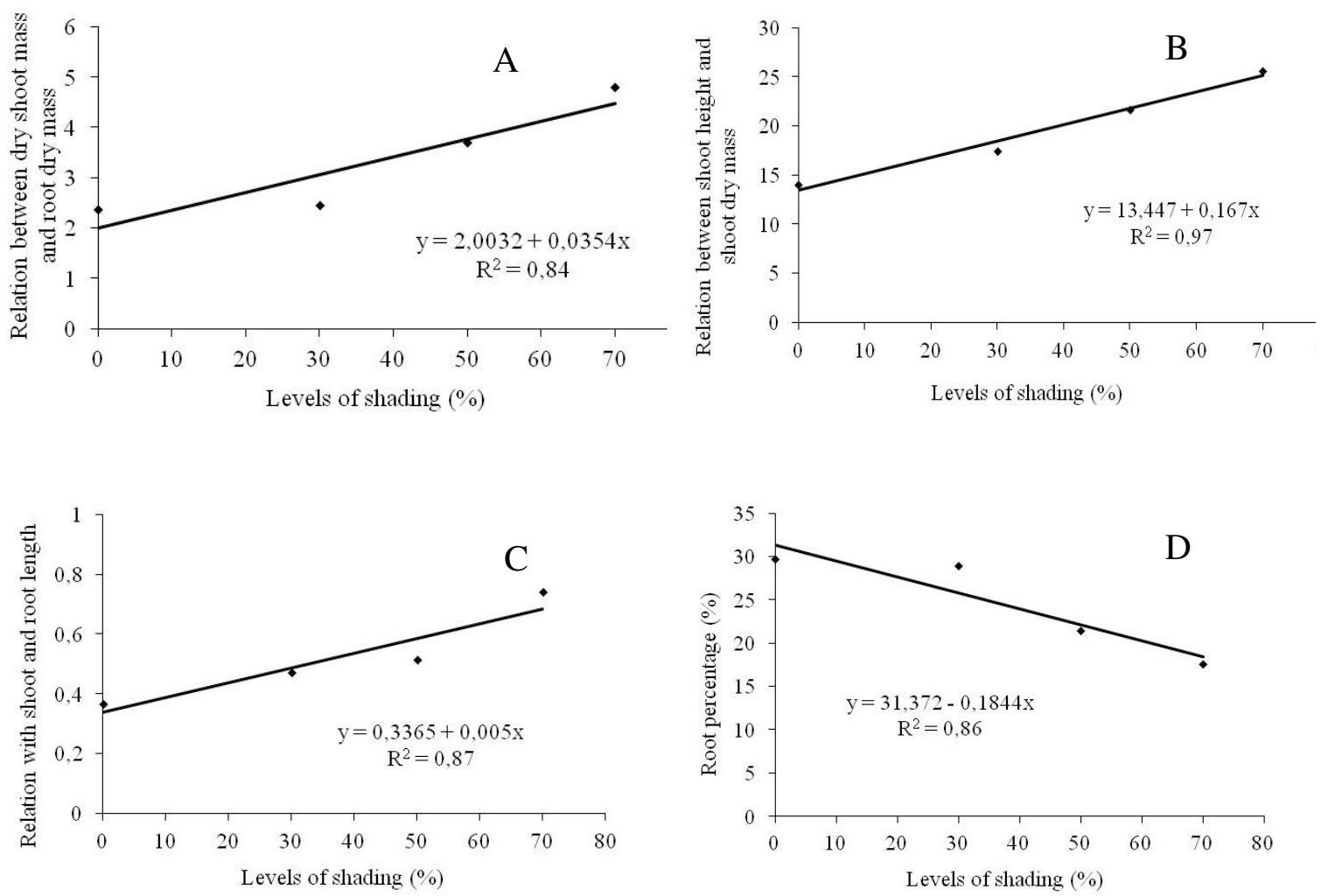

Figure 4. Ratio between the dry mass of shoots and roots (MSPA/MSR) - (A), plant height and weight of shoot (AP/MSPA) - (B), length of shoot and primary root (CPA/CR) - (C) and percentage of roots (\% R) - (D) of Dimorphandra gardneriana seedlings produced at different levels of shading.

Table 2. Pearson correlation coefficients between the green mass of shoots (MVPA) and roots (MVR), dry mass of roots (MSR) and shoots (MSPA), total dry mass (MST), length of primary root (CR) and shoot (CPA), Dickson quality index (DQI), ratio of the dry mass of shoots and roots (MSPA/MSR), plant height and dry mass of shoots (AP/MSPA), length of shoot and primary root (CPA/CR) and percentage of roots (\% R) of Dimorphandra gardneriana seedlings.

\begin{tabular}{cccccccccccc}
\hline Variables & MVPA & MSR & MSPA & MST & CPR & CPA & IQD & MSPA/MSR & APA/MSPA & CPA/CR & $\% \mathrm{R}$ \\
\hline MVR & $0,65^{*}$ & $0,88^{* *}$ & $0,62^{* *}$ & $0,73^{* *}$ & $0,80^{* *}$ & $-0,31^{\mathrm{ns}}$ & $0,87^{* *}$ & $-0,79^{* *}$ & $-0,87^{* *}$ & $-0,64^{* *}$ & $0,87^{* *}$ \\
MVPA & - & $0,65^{* *}$ & $0,86^{* *}$ & $0,83^{* *}$ & $0,54^{*}$ & $-0,76^{* *}$ & $0,57^{*}$ & $-0,79^{* *}$ & $-0,74^{* *}$ & $-0,82^{* *}$ & $0,80^{* *}$ \\
MSR & - & - & $0,80^{* *}$ & $0,88^{* *}$ & $0,86^{* *}$ & $-0,21^{\mathrm{ns}}$ & $0,98^{* *}$ & $-0,81^{* *}$ & $-0,90^{* *}$ & $-0,60^{* *}$ & $0,90^{* *}$ \\
MSPA & - & - & - & $0,98^{* *}$ & $0,64^{*}$ & $-0,47^{*}$ & $0,74^{* *}$ & $-0,73^{* *}$ & $-0,73^{* *}$ & $-0,63^{* *}$ & $0,79^{* *}$ \\
MST & - & - & - & - & $0,72^{* *}$ & $-0,40^{\mathrm{ns}}$ & $0,83^{* *}$ & $-0,75^{* *}$ & $-0,80^{* *}$ & $-0,63^{* *}$ & $0,83^{* *}$ \\
CPR & - & - & - & - & & $-0,24^{\mathrm{ns}}$ & $0,89^{* *}$ & $-0,66^{* *}$ & $-0,85^{* *}$ & $-0,68^{* *}$ & $0,74^{* *}$ \\
CPA & - & - & - & - & - & - & $-0,12^{\mathrm{ns}}$ & $0,58^{*}$ & $0,51^{*}$ & $0,86^{* *}$ & $-0,53^{*}$ \\
IQD & - & - & - & - & - & - & - & $-0,76^{* *}$ & $-0,86^{* *}$ & $-0,53^{*}$ & $0,85^{* *}$ \\
MSPA/MSR & - & - & - & - & - & - & - & - & $0,82^{* *}$ & $0,78^{* *}$ & $-0,97^{* *}$ \\
APA/MSPA & - & - & - & - & - & - & - & - & - & $0,81^{* *}$ & $-0,89^{*}$ \\
CPA/CR & - & - & - & - & - & - & - & - & - & - & $-0,77^{* *}$ \\
$\% \mathrm{R}$ & - & - & - & - & - & - & - & - & - & - & 1 \\
\hline
\end{tabular}

** significant at $1 \%, *$ significant at $5 \%$ probability. ${ }^{\text {ns }}$ Not significant. 
The percentage of roots was correlated significantly and negatively with the length of the shoot and ratios of dry weight of shoots and roots, plant height and dry weight of shoots, and shoot length and primary root, however, this correlation with other variables was significant and positive, whereas the survival rate did not correlate with any of the variables evaluated (Table 2).

The presence of a significant negative correlation between variables indicated that there is inversely proportional behavior between them, or as one increased the other decreased, such as the significant negative correlation between the length of shoots and green and dry mass shoots, since the greater height did not correspond to the maximum green and dry mass content. However, the positive and significant correlation indicated that the increase of one implies the gain of the other, emphasizing the DQI, which together with the green and dry mass of roots and shoots and total dry mass, as well as the primary root length are important variables in determining the quality of $D$. gardneriana seedlings.

The seedlings of $D$. gardneriana produced in full sun showed superior characteristics to those produced in the shade, indicating greater adaptability to high light conditions. In this sense, Freitas et al. (2012) point out that the greater adaptability of the species to the high incidence of light could ensure the success of a degraded area recovery project, and pioneer and early secondary species are recommended to start the successional stages in recovery projects of degraded areas, owing to their adaptation to most light conditions.

Therefore, it should be emphasized that knowledge of potential use, physiology, management and seedling production can contribute both to the maintenance of forests and planning the environmental restoration of the original vegetation (ALMEIDA et al., 2005). Many native species are potentially suitable for rational cultivation and can be used for several purposes, including ornamental, wood, food, medicinal, and preservation.

\section{CONCLUSIONS}

Seedlings produced in full sun had higher values of the characteristics (number of leaves, root length, green and dry mass of root and shoot and total, DQI, and highest percentage of root) than those produced in shade.

Based on the morphological parameters studied, it can be affirmed that the $D$. gardneriana Tul., seedlings, produced in an open environment with high luminosity showed superior qualities in relation to the shaded seedlings.

RESUMO: O estudo do comportamento de plantas em ambientes com diferentes intensidades luminosas oferece informações sobre a capacidade que elas têm em modificar seu crescimento e desempenho em resposta à luminosidade. Assim, objetivou-se avaliar a influência do sombreamento no desenvolvimento das mudas de Dimorphandra gardneriana Tul. Foram utilizados diferentes níveis de sombreamentos, sendo estes compostos por $0 \%$ de sombreamento (pleno sol) $\left(\mathrm{T}_{1}\right), 30 \%-\left(\mathrm{T}_{2}\right), 50 \%-\left(\mathrm{T}_{3}\right)$ e $70 \%$ de sombreamento - $\left(\mathrm{T}_{4}\right)$. A obtenção dos diferentes níveis de sombreamento foi por meio de telas de poliolefinas de cor preta, tipo sombrite, sendo cada tratamento composto por quatro repetições de 15 plantas. As características avaliadas foram: o número de folhas, altura da planta, diâmetro do colo, porcentagem de sobrevivência, comprimento de parte aérea e raiz primária, massa verde e seca da parte aérea e raízes, massa seca total, índice de qualidade de Dickson e a relação entre altura e diâmetro do colo (A/DC), massa seca da parte aérea e das raízes (MSPA/MSR), altura de planta e massa seca da parte aérea (AP/MSPA), comprimento da parte aérea e da raiz primária (CPA/CR), assim como a porcentagem de raízes (\%R). O sombreamento influenciou negativamente a qualidade das mudas de D. gardneriana, sendo aquelas cultivadas a pleno sol as que apresentaram melhor qualidade. Com base nos parâmetros morfológicos estudados, pode-se afirmar que as mudas de D. gardneriana Tul., Produzidas em ambiente aberto com alta luminosidade, apresentaram qualidades superiores em relação às plântulas sombreadas.

PALAVRAS-CHAVE: Fava d'anta. Espécie florestal. Luminosidade.

\section{REFERENCES}

ALMEIDA, L. S.; MAIA, N.; ORTEGA, A. O.; ANGELO, A. C. Crescimento de mudas de Jacaranda puberula Cham. em viveiro submetidas a diferentes níveis de luminosidade. Ciência Florestal, Santa Maria, v. 15, n. 3, p. 323-329, 2005.

AZEVEDO, G. T. O. S.; NOVAES, A. B.; AZEVEDO, G. B.; SILVA, H. F. Desenvolvimento de mudas de nim indiano sob diferentes níveis de sombreamento. Floresta e Ambiente, Seropédica, v. 22, n. 2, p. 249-255, 2015. 
CARON, B. O.; SOUZA, V. Q.; CANTARELLI, E. B.; MANFRON, P. A.; BEHLING, A.; ELOY, E. Crescimento em viveiro de mudas de Schizolobium parahyba (Vell.) S. F. Blake. submetidas a níveis de sombreamento. Ciência Florestal, Santa Maria, v. 20, n. 4, p. 683-689, 2010.

CHEN, H.; MIAO, Q.; GENG, M.; LIU, J.; HU, Y.; TIAN, L.; PAN, J.; YANG, Y. Anti-tumor effect of rutin on human neuroblastoma cell lines through inducing G2/M cell cycle arrest and promoting apoptosis. The Scientific World Journal, v. 2013, Article ID 269165, 8 pages, 2013.

COSTA, E. C.; D'AVILA, M.; CANTARELLI, E. B.; MURARI, A. B.; MANZONI, C. G. Entomologia florestal. Santa Maria: UFSM, 2008. 240p.

DICKSON, A.; LEAF, A. L.; HOSNER, J. F. Quality appraisal of white spruce and white pine seedling stock in nurseries. Forest Chronicle, Ontário, v. 36, n. 1, p. 10-13, 1960. https://doi.org/10.5558/tfc36010-1

DUTRA, T. R.; GRAZZIOTTI, P. H.; SANTANA, R. C.; MASSAD, M. D. Qualidade de mudas de copaíba produzidas em diferentes substratos e níveis de sombreamento. Floresta, Curitiba, v. 45, n. 3, p. 635-644, 2015. https://doi.org/10.5380/rf.v45i3.35686

FLOSS, E. L. Fisiologia das plantas cultivadas: o estudo que está por trás do que se vê. 2.ed. Passo Fundo: UPF, 2004. 536p.

FONSECA, E. P.; VALÉRI, S. V.; MIGLIORANZA, E.; FONSECA, N. A. N.; COUTO, L. Padrão de qualidade de mudas de Trema micrantha (L.) Blume, produzidas sob diferentes períodos de sombreamento. Revista Árvore, Viçosa, v. 26, n. 4, p. 515-523, 2002.

FREITAS, G. A.; VAZ-DE-MELO, A.; PEREIRA, M. A. B.; ANDRADE, C. A. O.; LUCENA, G. N.; SILVA, R. R. Influência do sombreamento na qualidade de mudas de Sclerolobium paniculatum Vogel para recuperação de área degradada. Journal of Biotechnology and Biodiversity, Palmas, v. 3, n. 3, p. 5-12, 2012.

FRIGOTTO, T.; BRUN, E. J.; MEZZALIRA, C. C.; NAVROSKI, M. C.; BIZ, S.; RIBEIRO, R. R.

Desenvolvimento de mudas de Schizolobium amazonicum Huber ex Ducke em diferentes ambientes em viveiro. Ecologia e Nutrição Florestal, Santa Maria, v. 3, n. 1, p. 9-17, 2015.

GEYBELS, M. S.; VERHAGE, B. A.; ARTS, I. C.; VAN SCHOOTEN, F. J.; GOLDBOHM, R. A.; VAN DEN BRANDT, P. A. "Dietary flavonoid intake, black tea consumption, and risk of overall and advanced stage prostate cancer,” American Journal of Epidemiology, v. 177, n. 12, p. 1388-1398, 2013.

https://doi.org/10.1093/aje/kws419

GOMES, J. M.; PAIVA, H. N. Viveiros florestais: propagação sexuada, 1.ed., Ed. UFV, Viçosa, 2013. 116p.

LANDIM, L. P.; COSTA, J. G. M. Dimorphandra gardneriana Tulasne (fava d'anta) - uma abordagem etnobotânica e riscos de extinção. Revista da Biologia, São Paulo, v. 9, n. 1, p. 6-11, 2012.

https://doi.org/10.7594/revbio.09.01.02

LEI, T. T.; LECHOWICZ, M. J. Diverse responses of maple saplings to forest light regimes. Annals of Botany, Oxford, v. 82, n. 1, p. 9-19, 1998. https://doi.org/10.1006/anbo.1998.0644

LIMA, J. D.; SILVA, B. M. S.; MORAES, W. S.; DANTAS, V. A. V.; ALMEIDA, C. C. Efeitos da luminosidade no crescimento de mudas de Caesalpinia ferrea Mart. Ex Tul. (Leguminosae, Caesalpinoideae). Acta Amazonica, Manaus, v. 38, n. 1, p. 5-10, 2008. https://doi.org/10.1590/S0044-59672008000100002

MARCO, R.; CONTE, B.; PERRANDO, E. R.; FORTES, F. O.; SOMAVILLA, L.; BURGIN, M. B. Efeito de telas de sombreamento no crescimento e proteção de mudas de Toona ciliata sob baixas temperaturas. Floresta, Curitiba, v. 44, n. 4, p. 607-616, 2014. https://doi.org/10.5380/rf.v44i4.33126 
MONTANO, H. G.; SILVA, G. S.; ROCHA, R. C.; JIMENEZ, N. Z. A.; PEREIRA, R. C.; BRIOSO, P. S. T. Phytoplasma in "fava d'anta" tree (Dimorphandra gardneriana) in Brazil. Bulletin of Insectology, Bolonha, v. 60, n. 2, p. 147-148, 2007.

POORTER, L. Growth responses of 15 rain-forest tree species to a light gradient: the relative importance of morphological and physiological traits. Functional Ecology, London, v. 13, n. 3, p. 396-410, 1999.

https://doi.org/10.1046/j.1365-2435.1999.00332.x

QUEIROZ, S. E. E.; FIRMINO, T. O. Efeito do sombreamento na germinação e desenvolvimento de mudas de baru (Dipteryx alata Vog.). Revista Biociências, Taubaté, v. 20, n. 1, p. 72-77, 2014.

RIBEIRO-SILVA, S. Ecologia de populações e Aspectos etnobotânicos de Dimorphandra gardneriana. (Tulasne) na Chapada do Araripe, Ceará. 2007. 105p. Tese (Doutorado em Ecologia) - Universidade de Brasília, Brasília, 2007.

RIBEIRO-SILVA, S.; SCARIOT, A.; MEDEIROS, M. B. Uso e Práticas de manejo de faveira (Dimorphandra gardneriana Tul.) na região da Chapada do Araripe, Ceará: implicações ecológicas e sócio-econômicas.

Biodiversidade Brasileira, Brasília, v. 2, n. 2, p. 65-73, 2012.

SANTOS, L. W.; COELHO, M. F. B.; AZEVEDO, R. A. B. Qualidade de mudas de pau-ferro produzidas em diferentes substratos e condições de luz. Pesquisa Florestal Brasileira, Colombo, v. 33, n. 74, p. 151-158, 2013. https://doi.org/10.4336/2013.pfb.33.74.344

SANTOS, U. F.; XIMENES, F. S.; LUZ, P. B.; SEABRA JÚNIOR, S.; SOBRINHO, S. P. Níveis de sombreamento na produção de mudas de pau-debalsa (Ochroma pyramidale) Bioscience Journal, Uberlândia, v. 30, n. 1, p. 129-136, 2014.

SARAIVA, G. F. R.; SOUZA, G. M.; RODRIGUES, J. D. Aclimatação e fisiologia de mudas de guanandi cultivadas em telas de sombreamento foto-protetoras. Colloquium Agrariae, Presidente Prudente, v. 10, n. 2, p. 1$10,2014$.

URSULINO, M. M. Tecnologia de sementes de Dimorphandra gardneriana Tulasne. 2013. 89f.

Dissertação (Mestrado em Agronomia) - Centro de Ciências Agrárias. Universidade Federal da Paraíba, Areia, 2013. 